\title{
Refuge
}

Canada's Journal on Refugees

revue canadienne sur les réfugiés

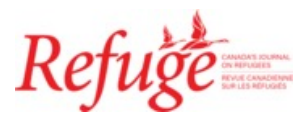

\section{The Borders of Tropicality}

\section{Julián Gutiérrez Castaño}

Volume 35, Number 1, 2019

\section{Racialized Refuge}

URI: https://id.erudit.org/iderudit/1060672ar

DOI: https://doi.org/10.7202/1060672ar

See table of contents

Publisher(s)

Centre for Refugee Studies, York University

ISSN

0229-5113 (print)

1920-7336 (digital)

Explore this journal

Cite this article

Gutiérrez Castaño, J. (2019). The Borders of Tropicality. Refuge, 35(1), 18-31. https://doi.org/10.7202/1060672ar

\section{Article abstract}

This article argues that the discourse of tropicality in Colombia creates boundaries and binaries between racialized and normative territories, rural peripheral areas and urban centres, and spaces that have been constructed as darker "barbaric" regions closer to sea level and whiter "civilized" regions in temperate altitudes. Nevertheless, there is nuance to the geographies of tropicality, because race is difficult to contain within urban/rural spaces. Additionally, race as a social construct that is permanently in the making, presents changes in space and time, challenging any static ideas of race in intersection with geography. In supporting the argument that the discourse of tropicality produces racialized spaces, this article addresses forced displacement and the racialization that takes place along with displacement, which implies the crossing of the "border" between the "tropics" and the cities; and how Afro-Colombians, Indigenous, and Mestiza campesinas challenge the ideas of tropicality by creating new geographies as they settle after displacement.
Copyright (c) Refuge: Canada's Journal on Refugees, 2019

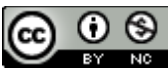

This document is protected by copyright law. Use of the services of Érudit (including reproduction) is subject to its terms and conditions, which can be viewed online.

https://apropos.erudit.org/en/users/policy-on-use/ 


\title{
The Borders of Tropicality
}

\author{
JULIÁN GUTIÉRREZ CASTAÑO ${ }^{1}$
}

\section{Abstract}

This article argues that the discourse of tropicality in Colombia creates boundaries and binaries between racialized and normative territories, rural peripheral areas and urban centres, and spaces that have been constructed as darker "barbaric" regions closer to sea level and whiter "civilized" regions in temperate altitudes. Nevertheless, there is nuance to the geographies of tropicality, because race is difficult to contain within urban/rural spaces. Additionally, race as a social construct that is permanently in the making, presents changes in space and time, challenging any static ideas of race in intersection with geography. In supporting the argument that the discourse of tropicality produces racialized spaces, this article addresses forced displacement and the racialization that takes place along with displacement, which implies the crossing of the "border" between the "tropics" and the cities; and how Afro-Colombians, Indigenous, and Mestiza campesinas challenge the ideas of tropicality by creating new geographies as they settle after displacement.

\section{Résumé}

Cet essai soutient que le discours de la tropicalité en Colombie crée des frontières et des oppositions binaires entre territoires racialisés et normatifs, entre régions rurales périphériques et centres urbains ainsi quentre les régions près du niveau de la mer construites comme étant plus foncées et "barbares» et les régions tempérées dites plus blanches et "civilisées» situées en altitude. Les géographies de la tropicalité sont cependant plus nuancées car la race est difficile à contenir à l'intérieur d'espaces urbains ou ruraux. De plus, la race est un construit social en devenir permanent qui change à travers le temps et l'espace, ce qui remet en question toute idée statique concernant son intersection avec la géographie. Soutenant l'argument selon lequel le discours de la tropicalité produit des espaces racialisés, cet article traite du déplacement forcé et du processus de racialisation qui accompagne le processus de déplacement, qui implique la traversée de la frontière entre les «tropiques» et les villes; et de la façon dont les campesinas afrocolombiens, autochtones et Mestiza, en s'installant suite au déplacement, créent de nouvelles géographies qui remettent en question l'idée de tropicalité.

\section{Introduction}

In November 1998 I had to run away from home because of the violence. It was during the night of November 7. I was pregnant. My route involved going through a farm that has a steep hill.... I managed to arrive in the early morning. I had my baby about one hour after.... Two days later, we learnt that we had to leave.... Some members of the community carried me down on a hammock. We
(C) Julián Gutiérrez Castaño, 2019. This open-access work is licensed under a Creative Commons Attribution-NonCommercial 4.0 International Licence, which permits use, reproduction, and distribution in any medium for non-commercial purposes, provided the original authorship is credited and the original publication in Refuge: Canada's Journal on Refugees is cited.
Cette œuvre en libre accès fait l'objet d'une licence Creative Commons Attribution-NonCommercial 4.o International License, laquelle autorise l'utilisation, la reproduction et la distribution de l’euvre sur tout support à des fins non commerciales, pourvu que l'auteur ou les auteurs originaux soient mentionnés et que la publication originale dans Refuge: revue canadienne sur les réfugiés soit citée. 
had to walk on a hidden path because the paramilitaries were watching from helicopters. When I arrived at my village, I looked around and it was a sad image, everybody had left.... Around midnight we heard that we had to leave because the paramilitaries were arriving. We had to get up and walked for more than fourteen hours, walking up and down steep hills. When we were getting close to Ríoviejo ... I couldn't take it anymore, I didn't know where to put my feet, I was dying of thirst and hunger. I drank from a pothole with yellow water, I was so desperate. I was carried in an ambulance to the hospital. I didn't feel when they put me in bed. I had a $42^{\circ} \mathrm{C}$ fever, and my body ached as if someone had beaten me badly. After this, the paramilitaries arrived, the guard and nurse hid me in a hole behind the hospital, where I had to remain with my partner and baby for hours. The hospital personnel weren't allowed to see the people that were arriving. According to the paramilitaries, we were all guerrillas. ${ }^{2}$

The testimony above speaks of the terrible violence and forced displacement that are characteristic of the Colombian social and armed conflict, but it also reflects another dynamic that is the main concern of this article. The division and transition between rural marginalized spaces and central urban spaces, a separation that overlaps with the spaces where people are being dispossessed of their land and means of production, and the spaces where they arrive after being forcibly displaced. This article argues that this is a division between racialized spaces that the discourse of tropicality has represented as darker "barbaric" regions closer to sea level, and normative spaces that have been constructed as whiter "civilized" regions in temperate altitudes. The movement of Colombia's internally displaced persons (IDPs) is a dislocation that causes a new racialization, as people who had not necessarily confronted racism in the micro-geographies of daily life before dispossession and displacement become a new kind of racialized subjects. The racialization that takes place during the movement from their original territories does not affect individuals only. In addition to the historic racialization of Afro-Colombians, Indigenous peoples, and Mestiza campesinas, ${ }^{3}$ they are now categorized in an eclectic group that contains more than seven million IDPs in Colombia. ${ }^{4}$ In other words, forced displacement also creates new forms of racialization.

This article builds on the work of authors who have advanced critical race studies in Colombia. Peter Wade has studied the complexity of racial identity in Colombia and how the ideology of Mestizaje has influenced the national discourse, particularly in the Colombian versions of liberalism and multiculturalism. ${ }^{5}$ Arturo Escobar has theorized the relation between race, racism, and the discourse of development, uncovering the connection between Colombia’s national discourse of progress and violence. ${ }^{6}$ His work has been complemented by Ulrich Oslender, who researches the dialectic relation of development and forced displacement. ${ }^{7}$ Eduardo Restrepo, although focusing mostly on the Afro-Colombian population, has made a tremendous contribution to critical race studies in Colombia. His work on racialization as a dynamic process, in opposition to the traditional understanding of racial categories as static and fixed, had an important influence on this paper. ${ }^{8}$ Finally, the study of Santiago Castro-Gómez about science and race during the Enlightenment in Colombia, particularly his insights into the discourse of tropicality, has helped me to understand how this discourse was influential during the birth of the nation and its pervasive impact in the past and the present. ${ }^{9}$ This article furthers critical race studies in Colombia by reflecting on the discourse of tropicality in the present and articulating the relation between forced displacement and racialization.

This article is divided into five sections. The first explains the methodology used in the research from which this article springs. The second section explores the concept of tropicality in Colombia, which grounds the other sections geographically and explains how forced displacement can be understood in connection with cultural and racial dynamics. The third segment deals with the relation between race and forced displacement using national statistics on Colombia's population, racial categories, displacement, and geographical information. The fourth part draws theoretically from post-structuralist, Marxist, critical geographies of race, and post-colonial literature to explain the rationality behind the dispossession of Indigenous peoples, Afro-Colombians, and Mestiza campesinas. This segment complements the previous section by addressing the dialectical relation between racism and forced displacement, identifying racism as a cause of displacement, and displacement as a source of racialization. The final section explores how IDPs, who have been racialized as an entire group through displacement, challenge the geographical divisions imposed by tropicality and understandings that reduce their lives to bare life, ${ }^{10}$ mainly by reclaiming and practising the rights to the city ${ }^{11}$ and to mobility.

\section{Methodology}

This article uses a qualitative methodology that combines interviews, field diary, photography, and revision of institutional reports from government agencies and nongovernmental organizations (NGOS). This research consists of twelve interviews conducted during the summer of 2014 in Colombia's coffee region. Eight were individual structured interviews, one was a collective structured interview with three participants, and three were semi-structured interviews. The interviews followed a snowball technique, selecting the interviewees from a combination of previous contacts who 
were familiar with race studies, further snowballing samples and IDPs. While selecting the interviewees, I kept in mind the importance of having diversity of gender, class, ethnicity, and age, among others, in order to reflect different points of view and experiences of racialization. Seven women and seven men were interviewed, four of them self-identified as Afro-Colombians, five as Indigenous, three as Mestizas, and two as White Europeans. Interviewees' ages ranged between the twenties and sixties.

During the first interviews, I learned that the format needed to be more flexible in order to accommodate all interviewees. This flexibility was allowed in two situations. First, the structured format was modified from structured to semi-structured interview, when interviewees took the initiative and addressed some of the questions I had prepared even before I asked them. This flexibility gave interviewees the freedom to expand and emphasize the aspects that were more important for them. Second, before the interviews, participants were offered a written informed consent, which they were asked to sign. It became very clear from the beginning that for some of the interviewees signing any kind of consent was extremely uncomfortable, even traumatic. Some of the interviewees did not know how to read and write, or had very low literacy levels. Even more important, some of the interviewees had been dispossessed with the manipulation of written documents. As soon as I recognized these difficulties, I started using an oral informed consent, which avoided the discomfort of having to sign a document, but allowed them to learn about the research, its ethics protocol, the voluntary character of their participation, and the responsibilities that I had with them as a researcher.

\section{Tropicality in Colombia}

The geography of displacement and racism can be useful to recognize the borders of tropicality, although I must clarify that I am not trying to establish these borders. I am simply acknowledging their poignant presence. Tropicality is a geographical concept that helps to understand the construction and othering of racialized subjects, mainly by establishing a form of "environmental Eurocentrism." ${ }^{2}$ This critique is inspired by and similar to Edward Said's work on Orientalism, ${ }^{13}$ more concretely when it addresses the construction of European identity in a dialectical relation with the "Oriental Other." In the case of tropicality, whiteness is built in opposition to the "Tropical Other." Clayton and Bowd define tropicality as "a discourse-or complex of Western ideas, attitudes, knowledges and experiences-that, since the fifteenth century, has both created and been shaped by distinctions between temperate and tropical lands, with the temperate world routinely exalted over its tropical counterpart, and tropicality becoming central to the definition of the West as a temperate (moderate and hard-working rather than extreme and indolent) human as well as physical environment." ${ }^{14}$

The discourse of tropicality can be employed to understand climatic racism and other forms of environmental determinism that have been used to justify European colonization, and that has been adapted by European descendants (Whites) and Mestizas with aspirations to whiteness in nation-states such as Colombia. Tropicality justifies an imaginary geographical division between this group, on one hand, and Indigenous people, Afro-Colombians, and Mestiza campesinas on the other. Like orientalists, tropicalists collapse "geographical and 'civilizational' divides"15 to construct identity and otherness.

The discourse of tropicality in Colombia has its roots in the late seventeenth century, first as an initiative of the Spanish Crown, later as a project undertaken by the local elite. The most important representative of this project was the scientist Francisco José de Caldas, often referred as "el sabio," the learned. His most ambitious project was to develop a geographic encyclopedia that covered the territory of the Viceroyalty of Nueva Granada. ${ }^{16}$ This was a modernizing project that sought to map the natural characteristics of each region, along with its weather, economic potential, and population, with the objective of increasing agricultural productivity. When mapping the population, emphasis was put on understanding its characteristics and traditions, and examining the moral and physical characteristic of the different racial groups in Nueva Granada, to establish a causal relation between their geographical location and their identities. For Caldas, the most determinant factor for variations between the regions was the altitude - an idea that became very popular among the academic and economic elites. ${ }^{17}$ These ideas were reflected in the Casta system, a hierarchical racial and social structure imposed by Latin American White elites, who were Spanish or their descendants. The Casta system institutionalized White privilege in the micro-geographies of everyday life, overseeing the most ordinary acts that people could or could not do on the basis of their race, and securing the highest positions in society for the White elite.

The imaginary geographical divisions imposed by the discourse of tropicality in Colombia are marked by two contradictions. First, Colombia's territory lies entirely within the tropical region of the Earth. Second, the division among different regions/populations is not clear-cut. Today, many Mestizas live in the racialized tropics as Mestiza campesinas, while historically many Indigenous people and AfroColombians have inhabited the cities. ${ }^{18}$ In consequence, Indigenous peoples, Afro-Colombians, and Mestizas (urban and campesinas) have different experiences of racialization, othering, and inclusion/exclusion, depending on the 
spaces where they are permanently or temporally situated. Recognizing these contradictions, I argue that today the imaginary borders of tropicality are porous, located not so much between the tropics and the highlands, as between rural peripheral areas and the cities. Although the borders of tropicality are not delineated in maps, they are real and oppressive. These borders encapsulate the "indefinable and impossible identities" that emerge as a consequence of colonial racialization, "identities which are ... regarded as non-identities." ${ }^{19}$

The first thing that they [city government] asked us, ... "What are you doing here? Why are you coming to the city when you belong in the mountains? Why are you here?" We kept silent most of the time, because we were afraid to explain many things. We were afraid to speak, to explain why we were in the city.... We're from the mountains, of course, we like them a lot, because we have everything there-we have our knowledge, our sacred places, our jaibe or spirit, because we're water, we're air, we're cloud. For these reasons we're from there, but the situation that we lived in the indigenous territories was very sad and difficult.

-Fernando

The testimony of Fernando, an Indigenous Embera leader whose community was displaced by the armed conflict from the West Andes to the city of Pereira, introduces various themes that I want to draw attention to. Local governments perform the role of the immigration official at the "border," keeping "tropical" subjects outside the gates of the more "civilized" spaces, where Indigenous and other racialized people "do not belong." It also speaks to the ambivalence of belonging to two different spaces: a traditional Indigenous territory in the mountains, and an urban territory where many Indigenous people, as well as Afro-Colombians and Mestiza campesinas, have been forced to move. In these urban spaces they are reclaiming and practising the right to the city. ${ }^{20}$ This spatial dichotomy is one of the most important elements of the interviews that I conducted. An aspect that reinforces the separation between the city and the racialized tropics is the construction of the coffee region's identity as Mestiza/Paisa, excluding Indigenous people and Afro-Colombians from its history and present. The narrative of the Antioqueño (Paisa) colonization myth originally claimed a White identity that finally settled for a Mestiza/White racial identity. According to Parsons, "The preponderance of mixed blood ... is in striking contradiction to the frequent assertion that Antioquia is a white province." ${ }^{21}$ There is a racial claim to ownership of the territory, which does not recognize that these spaces were Indigenous before the colonization and the existence of palenques (fortified communities created by runaway slaves) when these spaces were colonized. As Jackeline Mena, an
Afro-Colombian professor at Universidad Tecnológica de Pereira explains, "When you ask, 'What is the participation of Indigenous and Afro-Colombian communities in the construction of the landscape?', government officials and ordinary people ask you, 'What do you mean? The campesina is Antioqueña.' In consequence, Afro-Colombians do not belong in the coffee region, nor do Indigenous people, who are far away in their reserves."

Following the geographical separation represented in the discourse of tropicality, Indigenous and Afro-Colombian groups are understood and studied as ethnic categories, while Mestizas are lumped together with whiteness in a category that is constructed as the normative bodyscape of the nation ${ }^{22}$ and that is commonly understood as nonracialized. This idea is reinforced in the production of the most important sources of national statistics, such as the census, which categorizes 86 per cent of the Colombian population as Whites and Mestizas, and "not belonging to an ethnic group."23 This group is then assumed as the normative category, similar to whiteness in North America. ${ }^{24}$ After the separation of the territory into the racialized tropics and normative spaces, "ethnic groups" are then confined to the first, where they are supposedly left undisturbed, so they can practise their culture. They are seen as having static identities. In fact, they are pressured to remain the same and questioned when they change. Ironically, the discourse of tropicality sees them as "backward," but they are also condemned to what has been socially constructed as "backwardness" because Colombia's racial ideology does not allow them to transform. Their ethnic identities and culthures are fundamental in a racial project ${ }^{25}$ that presents Colombia as diverse and multi-ethnic, ${ }^{26}$ but their identities are unlike the identity of the normative subject of the nation. They are forced to become absurd museum identities/cultures that remind us of Balibar's ${ }^{27}$ indefinable and impossible identities. During an interview with Jessica, an Embera organizer in the city of Pereira, she challenged the idea that Indigenous people should remain constricted to what is understood as their traditional practices and territories. "Time changes. The new generations have changed too. Many people expect that Indigenous people stay in the mountain, in the river, without knowing what is happening in other places. They're selfish because they think that we have to stay there, but just as everything changes, just as everything flows, we, Indigenous people, we are also fluid."

The isolation of the tropics is breached when it is discovered that Afro-Colombian, Indigenous, and Mestiza campesina territories have valuable resources and/or when there are political motivations to gain more control over these spaces. The most damaging form of intervention due to external interests in these territories is a social and armed 


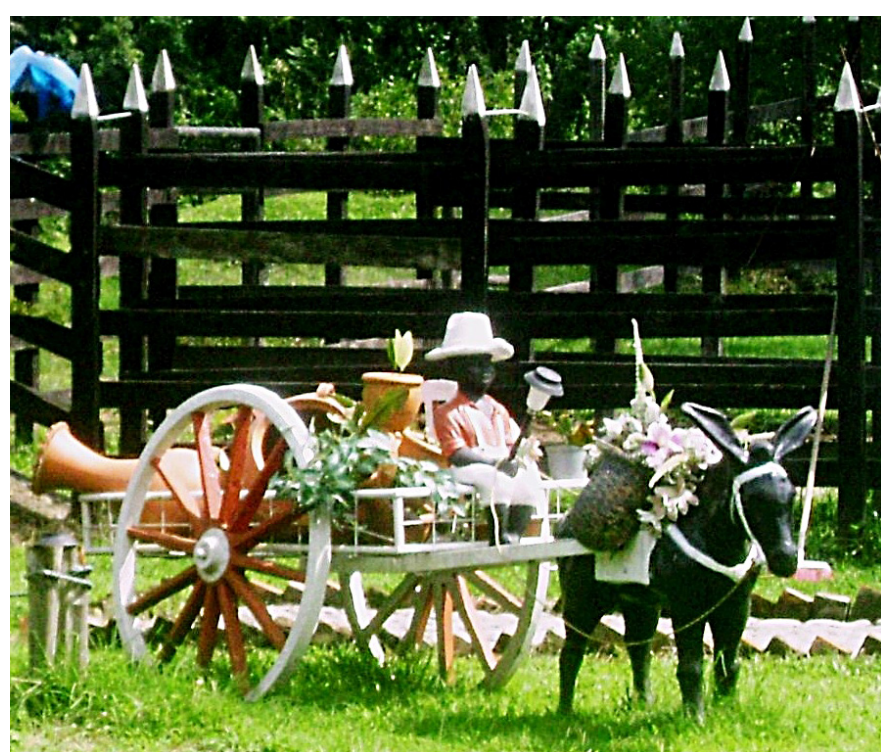

Figures of Afro-descendants reminiscent of the slavery era are a common sight at the entrance of upper-class country houses in the coffee region. These representations portray them as servants from a different era and distant geographies, emphasizing that they do not belong in the coffee region, but in the tropics.

conflict that involves guerrilla groups and the state (armed forces) in collusion with economic interests (multinationals, local economic interests, drug trafficking, and paramilitary groups). ${ }^{28}$ This conflict destroys community life, advances genocide in some of these communities and forces their displacement to other areas, particularly to urban centres. Afro-Colombians and Indigenous people have been subjected historically to racism, but for Mestiza campesinas who are displaced from territories where they have lived for generations, the displacement can be understood as a form of racialization that subjectified them to racism.

\section{Forced Displacement from Racialized Regions}

According to the Departamento Administrativo Nacional de Estadística (DANE), the Colombian government office in charge of national statistics, in 2005 the country had a population of $41,468,384$. Some $4,311,757$ (or 10.6 per cent) of the population identified as Afro-Colombians, while 1,392,623 (or 3.4 per cent) identified as Indigenous. The rest of the population (close to 86 per cent) was marked as not having an ethnic identity. ${ }^{29}$ These data can be misleading, since DANE basically grouped together the categories of White, Mestiza, and any other ethnic group that did not identify as Afro-Colombian, Indigenous, Raizal, or Roma. ${ }^{30}$ This initiative can be understood within the context of internalized racism and Mestizas' aspiration to whiteness, ${ }^{31}$ which drives Mestizas to distance themselves from brownness

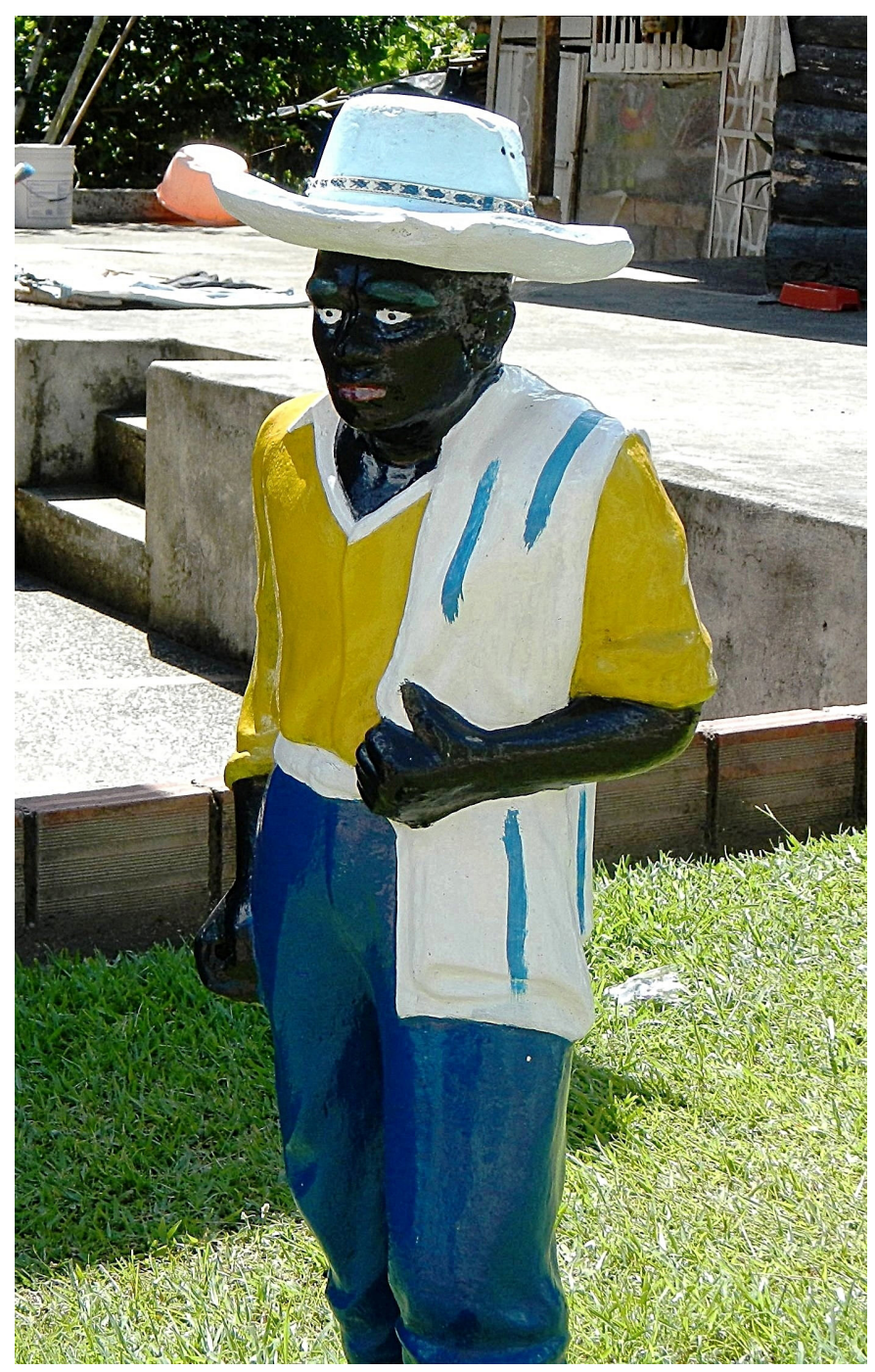

and blackness, denying central aspects of their identity, and reproducing racist dynamics that are damaging not only for Indigenous and Afro-descendants, but for Mestizas themselves. ${ }^{32}$ Mestiza is then officially conceptualized as the normative category, because its race and ethnicity are made invisible, it is strategically merged with whiteness, a category that historically has been built as not racialized, not part of any ethnicity, and has received racial privilege, ${ }^{33}$ although this article argues that there is more complexity within the category of Mestiza. Urban Mestizas are included in the normative bodyscape of the nation, while Mestiza campesinas are racialized by the discourse of tropicality in similar ways to Afro-Colombians and Indigenous peoples.

DANE reports that 14 per cent of the Colombian population identified as part of an ethnic minority. ${ }^{34}$ We could argue that any department in Colombia where more than 14 per cent of its population identifies as part of an ethnic minority 
Table 1: Forced Displacement by Department and Ethnicity

\begin{tabular}{|c|c|c|c|c|c|}
\hline Department & Total Population & $\begin{array}{l}\text { Afro-Colombian } \\
(\%)\end{array}$ & Indigenous (\%) & Source & $\begin{array}{l}\text { IDP crises/ } \\
\text { population }\end{array}$ \\
\hline Cauca & $1,268,937$ & 22.2 & 21.5 & $\begin{array}{c}\text { Acción Social, } \\
\text { CODHES } 38\end{array}$ & 33,393 \\
\hline Chocó & 454,030 & 82.1 & 12.7 & $\begin{array}{c}\text { Acción Social, } \\
\text { CODHES } 13\end{array}$ & 34,925 \\
\hline Valle Cauca & $4.161,425$ & 27.2 & 0.6 & $\begin{array}{l}\text { Acción Social, } \\
\text { CODHES } 14\end{array}$ & 297,744 \\
\hline Antioquia & $5,682.276$ & 10.9 & 0.5 & $\begin{array}{c}\text { Acción Social, } \\
\text { CODHES } 19\end{array}$ & 299.067 \\
\hline
\end{tabular}

Departments with the five worst crises of displacement according to incidence over the total population. Racialized territories are highlighted.

could be understood as a racialized territory in relation to other areas of the country. This observation has some weaknesses, as it assumes a regular and consistent distribution of ethnic groups along a political-administrative territory, but I still consider this indicator useful to draw a geography in which the relationship between racism and forced displacement is made explicit by highlighting the departments that have an ethnic population superior to the national average and comparing them with the departments that are more affected by forced displacement.

Colombia presents one of the worst crises of internally displaced persons (IDPS) in the world. ${ }^{35}$ The Colombian definition of IDPs corresponds to a predominant description as people who have been "uprooted by conflict, violence and persecution."36 Notice that the official understanding of IDPs does not include people who have been displaced by economic/development projects and natural disasters. A "person who has been forced to migrate within the national territory leaving behind his/her home and usual economic activities, because his/her life, physical integrity, security, and personal freedoms, have been violated and they are under threat by any of the following events: internal armed conflict, unrest and tensions, generalized violence, massive violations of human rights, infractions of the international human rights charter; and other circumstances related to the previous events that affect drastically the public order. -Article 1 , law 387 of $1997 .^{37}$

The exact number of IDPs in Colombia varies, depending on the source of information and period covered. According to Acción Social, the government office that oversaw internal displacement until 2010 and was replaced by the Departamento para la Prosperidad Social, there was an accumulation of 3,389,386 IDPs between 1996 and 2010. ${ }^{38}$ The Consejeria para los Derechos Humanos y el Desplazamiento (CODHES), an independent NGO that is highly respected for its work on human rights and forced displacement in Colombia, states that there have been 5,701,996 IDPs between 1985 and 2012. ${ }^{39}$ The United Nations High Commissioner for Refugees (UNHCR) calculates that the average population in forced displacement during the last twenty-five years sits at around 5,400,000. ${ }^{40}$ The Centro Nacional de Memoría Histórica (CNMH) estimates that close to seven million people have been displaced by this conflict. ${ }^{41}$ CODHES, UNHCR, and CNMH statistics include forced displacement caused by armed groups formed after the demobilization between paramilitaries and the Colombian government (2003-6), while government statistics do not reflect this source of displacement. ${ }^{42}$ CODHES reports that Indigenous peoples represent 7.08 per cent of IDPs in Colombia, in spite of the fact that they comprise only 3.43 per cent of the Colombian population; similarly, Afro-Colombians make up 22.5 per cent of IDPS in Colombia, but they are only 10.62 per cent of Colombia's population, according to the census. ${ }^{43}$ There is no statistic on Mestiza campesinas displaced by the conflict, but taking into consideration the census and the fact that people are displaced mostly from rural spaces, one can assume that they constitute most of the other 70 per cent of IDPs. The disproportionate impact of forced displacement over racialized people has also been acknowledged by government offices such as Acción Social and Defensoría del Pueblo, and international institutions like UNHCR. ${ }^{44}$

Table 1 and map 1 confirm that displacement in Colombia is a highly racialized problem. Following the Acción Social report, ten out of twenty departments that register internal 
displacement crises are territories with a larger racialized population. The incidence is even higher if we use the number of internal displacement emergencies registered by CODHES. In 2012, eight out of the fourteen departments that presented more forced displacement crisis were racialized territories, with Cauca, Chocó, Nariño, and Valle del Cauca registering more crises for every inhabitant. ${ }^{45}$ These four departments are located on the Pacific coast of Colombia, where more than 90 per cent of the population is of Afrodescendant, and 5 per cent is Indigenous. ${ }^{46}$ These departments are the spaces that the discourse of tropicality has represented as peripheral, racialized, darker, and barbaric. The following section explains how these markers are attached to these territories and its inhabitants, and the dialectical relation between racism and forced displacement.

\section{Dispossession and Racialization}

Modernization of the nation-state is intrinsically violent. In Colombia it implies the forced displacement of AfroColombians, Indigenous people, and Mestiza campesinas; the dispossession of their land for the benefit of agrobusiness, mining corporations, and other economic projects; and their forced integration into national and global economic circuits. ${ }^{47}$ This process targets these groups with biopower and discipline to get rid of traditional ways of life that differ drastically from capitalist modes of production. ${ }^{48}$ Afro-Colombians, Indigenous peoples, and Mestiza campesinas become more productive and competitive by embracing modernization and technology, or they must disappear as small farmers, ${ }^{49}$ an option that in the context of the Colombian armed conflict means being literally disappeared from the face of the earth or being displaced from their land..$^{50}$

The concepts of primitive accumulation ${ }^{51}$ and accumulation by dispossession ${ }^{52}$ are critical to understand forced displacement in the geographies that the discourse of tropicality has constructed as "extreme," "indolent," and "barbaric." Forced displacement has been an effective way to rob Indigenous peoples of their ancestral lands, ${ }^{53}$ Afro-Colombians from their legally recognized collective territories, and Mestiza campesinas from their historic territories. ${ }^{54}$ To a certain extent all these groups practise a relation with the land that differs from the form of private property inherent to capitalism. ${ }^{55}$ Forced displacement transforms the commons into modern private property, expanding the frontiers of capital by conquering new territories, particularly for industrial agriculture and extractive industries. The production shifts from a mixed economy of peasants' self-subsistence crops and commodities, to the exclusive production of commodities with exchange value. Simultaneously, Indigenous peoples, Afro-Colombians, and Mestiza campesinas are severed from

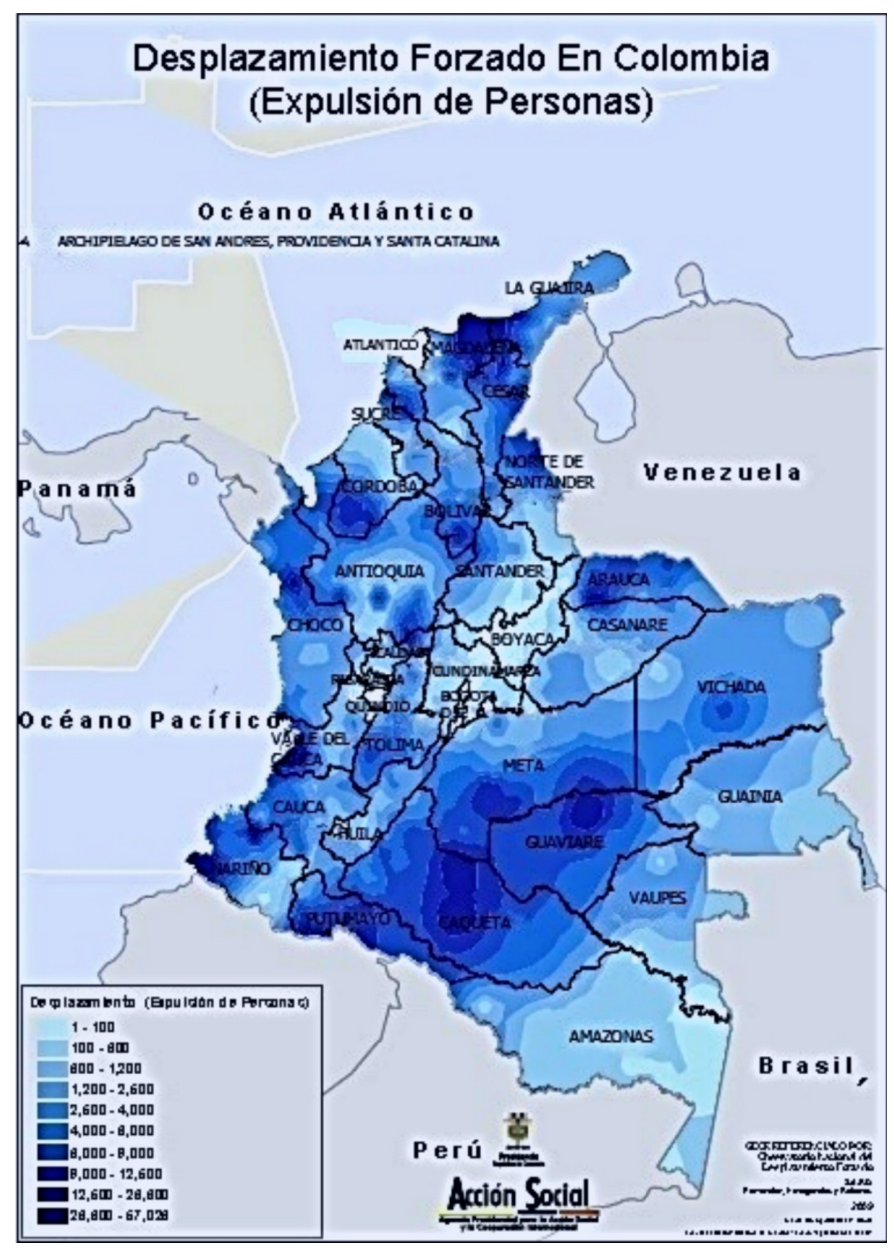

Map 1: Forced displacement in Colombia Departments of Colombia that present more internal displacement crises. Acción Social, Desplazamiento Forzado en Colombia.

their means of production. ${ }^{56}$ Finally, forced displacement creates surplus population ready to be incorporated into the workforce of the agro-industry and extractive industries in rural areas, or other industries in the city.

Harvey's accumulation by dispossession is understood as a continuous and necessary practice for the reproduction of capitalism. ${ }^{57}$ It includes, but it is not limited to "the commodification and privatization of land and the forceful expulsion of peasant populations...; conversion of various forms of property rights (common, collective, state, etc.) into exclusively private property rights; ... commodification of labor power and the suppression of alternative (indigenous) forms of production and consumption; colonial, neocolonial, and imperial processes of appropriation of assets (including natural resources); monetization of exchange and taxation, particularly of land." 58 
All these practices are present in Colombia's forced displacement, which affects particularly racialized people who inhabit the peripheral spaces that the discourse of tropicality has contributed to produce, while the central normative spaces become the receptors of IDPs. ${ }^{59}$ According to Harvey, this process is even more brutal in the Global South: "In developing countries, where opposition to neoliberalism and accumulation by dispossession can be stronger, the role of the neoliberal state quickly assumes that of active repression even to the point of low-level warfare against oppositional movements (many of which can now conveniently be designated as terrorist to garner U.S. military assistance and support)." ${ }^{\prime 60}$

This critique is very relevant in the Colombian context, where the United States has been heavily involved in the displacement of Indigenous peoples, Afro-Colombians, and Mestiza campesinas through its War on Drugs/Plan Colombia, which included the investment of billions of dollars for military purposes and the fumigation of extensive areas with Round-Up, destroying the means of subsistence of these populations. ${ }^{61}$

Forced displacement can be understood in connection to development. ${ }^{62}$ It reproduces neo-colonial relations of exploitation of the periphery by the metropole, ${ }^{63}$ benefiting corporations from the Global North, particularly mining and agro-business. ${ }^{64}$ It benefits Colombian economic elites ${ }^{65}$ in a process that can be framed as internal colonization, ${ }^{66}$ but that it is closely connected with neo-colonial dynamics, as national and international dominant classes share the same discourse of development ${ }^{67}$ and are responsible for what Oslender calls "a global capitalistic logic of displacement." In this sense, the division between the Global North and the Global South is not a simple geographical division based on national borders and stages of development, but a more complex spatial division that inherits from pockets of privilege within the North and the South. These spaces are reproduced even in the post-colonial era, creating spaces of exclusion and inclusion inside the nation-state. Class and race are decisive in the creation of these spaces, which Fanon qualifies as the "Manichean or compartmentalized structure of colonial society." ${ }^{39}$ National and international dominant classes share identity markers that define inclusion such as whiteness and economic privilege, in opposition to the excluded racialized and impoverished subjects. ${ }^{70}$ The discourse of tropicality in Colombia has been key to characterize and create boundaries between the racialized spaces inhabited by the last group, and the normative spaces settled by Whites and urban Mestizas.

In the Pacific region, where more than 90 per cent of the population is Afro-descendant and 5 per cent is Indigenous, ${ }^{71}$ the consequences of the discourse of tropicality are evident.
This is a racialized region made up by the coasts of the departments of Cauca, Chocó, Nariño, and Valle del Cauca, where forced displacement is more intense, as shown in map 1 and table 1. Afro-descendants, Indigenous people, and Mestiza campesinas have been displaced from their traditional territories by paramilitaries, state armed forces, and guerrillas. Their territories have been used to advance economic projects, such as oil palm and extraction of natural resources, that do not represent their interest, but that favour national and international dominant classes. ${ }^{72}$ According to Escobar, this displacement has racial motivations: "The end goal of the violence, as activists see it, is the disappearance of the ethnic groups of the Pacific as distinct cultures." ${ }^{33}$ This situation is not exclusive to Chocó. Urabá (Antioquia and Chocó), Magdalena Medio (Antioquia, Bolívar, Cesar, and Santander), and Nariño are other regions where I witnessed how Indigenous, Afro-descendants, and Mestizas campesinas are under attack and being forcibly displaced from their traditional lands. Forced displacement is seen on the surface as a consequence of the armed conflict, but the real cause is a combination of racism and economic development. ${ }^{74}$ Oslender argues that "forced displacement is not the result of the armed conflict, but its objective," ${ }^{\prime 7}$ where racialized subjects and entire regions have been dehumanized in a historical process of othering supported by the discourse of tropicality. Oslender echoes this geographical othering when addressing human rights violations in distant geographies, "in remote areas as in the Pacific coast. Who would go and check, after all?"76

One question that we must ask is about the fate of those who resist being integrated, the "people" who resist becoming "population," those whom the rational, modern state cannot entirely dominate with its biopower and power of discipline. Foucault points to the rational state invention to fill the void left by the dismissal of the sovereign's right to kill: racism of state. "What is in fact racism? It is primarily a way of introducing a break into the domain of life that is under power's control: the break between what must live and what must die." ${ }^{\text {"7 }}$ Those who "must die," according to the racist state in Colombia, seem to be the internally displaced: Indigenous people, Afro-Colombians, and Mestiza campesinas. As this article has already demonstrated, a disproportionate number of IDPs belong to "ethnic" groups, but I argue that the dispossession and displacement are themselves a process of racialization, of othering that divides those who must live from those who must die, either physically or symbolically.

According to Carlos Rosero, an Afro-Colombian activist, intellectual, and founder of the Black Communities Process (PCN), "The current wave of displacement is reminiscent of the times of slavery; the pain of family fragmentation, the impossibility of holding on to any territory, the pain and abuse 
suffered by women, the participation of men in an alien war, and the erosion of local authorities and autonomy." ${ }^{37}$ Displacement haunts Indigenous peoples and Afro-descendants with painful collective memories of colonization, slavery, and genocide; but it also creates new experiences of modernization and racialization that will haunt IDPs in the future. The intention to attack these groups and destroy their culture is clearly stated by Fernando, an Indigenous Embera leader: "We had to leave because we wanted to stay alive, to defend my father, because he's a Jaibaná. During those times the Jaibaná was persecuted by the leaders and the armed groups, because the Jaibaná represent a spiritual, human force within the community. So they were persecuted and killed with the objective of destroying the community."

\section{The Right to the City and the Right to Mobility}

Forced displacement constitutes the source of a "new chaos" that obliges people from multiple ethnicities to interact in Colombian urban spaces. It brings to the city Indigenous people, Afro-Colombians, and Mestiza campesinas, who have been historically, although not completely, excluded from the city. This interaction can have some positive outcomes, but it is mainly a traumatic experience for IDPs from rural peripheral areas. They face cultural shock on their arrival in the city, 79 they have to confront the racist stereotypes in the discourse of tropicality, and are discriminated for "being out of place," "homeless," "good for nothing," "Indios" (Indians), "Negros" (Blacks), and "campesinos." Fernando explains the difficult conditions that Embera IDPs faced when they arrived at the city: "We arrived directly to the streets, to the sidewalks in Pereira. We didn't have anything, only the clothes that we were wearing, because everything stayed there, our house, our animals, our crops, our land, everything remained there." Additionally, the social services provided by the state and other institutions such as churches and NGOS are not enough to facilitate the transition of IDPS into urban spaces.

Internally displaced Indigenous people, Afro-Colombians, and Mestiza campesinas are subjectified as Homo sacers condemned to bare life: "They constitute instead the originary exception in which human life is included in the political order in being exposed to an unconditional capacity to be killed." ${ }^{80}$ Subjectification is the act of the sovereign; in this case, the inclusion in the political order comes as a consequence of the forced displacement caused by the actors of the armed conflict (including, of course, the state): "The production of bare life is the originary activity of the sovereign." 1 However, the situations that I describe are not totalizing; they are challenged and transformed in multiples ways. For example, because IDPs, and particularly those who are classified as part of an ethnic group, are seen as belonging to the tropics, and their presence in the city is always questioned. In response, these populations claim a right to mobility. There is a sense of belonging to a place and, on the other hand, a need/desire to survive and have other experiences such as education, work, and life in the city. Urban Mestizas and Whites enjoy this right to mobility without being questioned, while Indigenous people, Afro-Colombians, and Mestiza campesinas have to validate it continuously. Jessica, an Embera organizer, addresses this erroneous belief directly: "We're in the city because we want to study, have some schooling because the job market ... they don't want to see us in the city, but they see it from a selfish point of view. It's as if we don't fit."

Indigenous people, Afro-Colombians, and Mestiza campesinas also reclaim and practise the right to the city. ${ }^{82}$ There is a sense among these communities that the urban spaces where they have been forced to move are their new territories, a place to stay. In consequence, they want to participate in the construction of public policy and the transformation of the city. This is done mostly through grassroots organizations and the support of NGOS. A very important development in many cities of Colombia is the establishment of urban cabildos (a structure of Indigenous government in resguardos, which are legally recognized Indigenous territories), with more than 170 being formed in Colombian cities. These initiatives face resistance from traditional Indigenous leaders on resguardos because they are afraid of losing power, do not know how to manage this new political geography, and have legitimate concerns about retaliation from the armed actors that caused the forced displacement. These armed groups still have control over Indigenous territories and do not want to draw attention to their operations. The appearance of urban cabildos raises questions about the Indigenous territories that its members had to abandon. On the other hand, local urban authorities oppose these initiatives because they are afraid of the new challenges and responsibilities that an urban cabildo would bring upon them. We can also identify a latent anxiety about the borders of tropicality and the fear that "the tropics" are taking over the city. Interestingly, urban cabildos are using community houses as a representation of their traditional territories. These are spaces where they practise their culture and sovereignty, such as cultural gatherings, political meetings, and Indigenous justice, even though there is tension between this attempt to practise sovereignty in the city and the ordinary justice system, which seeks to retain the borders of tropicality. The territorial jurisdiction of Indigenous justice is limited to rural resguardos, which are located precisely in the territories that the discourse of tropicality has marked as racialized.

Afro-Colombian communities are totally denied the possibility of having collective territories in urban spaces, a right 
that is constitutionally recognized in rural areas. ${ }^{83}$ Some Afro-Colombian leaders maintain that their organizations made a strategic mistake in the 1990 s when they undertook the issue of Afro-Colombian identity from an ethnic rights approach in the redaction of the new Colombian Constitution, rather than a civil rights approach. ${ }^{84}$ This strategy brought some success to Afro-Colombian communities as their collective territories were recognized, but it has forced them to frame their identity in terms similar to Indigenous nations when the realities of these two groups are not necessarily the same.$^{85}$ Américo Portocarrero, a professor at Fundación Universitaria del Area Andina and Afro-Colombian organizer, addressed this subject during an interview in the city of Pereira.

When the possibilities of the New Constitution emerged, at the beginning of the 1990s, these organizations weren't strong. This is the reason why Black communities didn't have representatives in the New Constitution, contrary to Indigenous communities. The lack of Black representatives in the Constitution forced them to look for alternatives to address their problems, and they found an ally in the Indigenous, but this had a very serious consequence, because the needs of the Blacks are not the same needs of the Indigenous, due to historical and cultural differences. But because of this relation, they were framed in a category similar to Indigenous ethnicity. In consequence, problems that should have been addressed in the same way that the issue was addressed in the United States, in the frame of civil rights, ended up subordinated to an ethnic claim, which was the approach that Indigenous people always had in Colombia: respect for their ethnic identity, their territories or resguardos, their culture and language. We ended up demanding ethnic rights.

\section{Conclusion}

The right to mobility and the right to the city that Indigenous peoples, Afro-Colombians, and Mestiza campesinas are reasserting with their practices demand an analysis in which their lives are not simply framed as bare life and they are not reduced to Homo sacers. ${ }^{86}$ There is a clear exercise of agency that questions the conditions that have been imposed on them and resilience to struggle for a better life. This dynamic has been recognized by scholars in other contexts. According to Rygiel's analysis of the "acts of citizenship" by undocumented immigrants in the Calais refugee camp, "The rights and ability of migrants [read IDPs] to settle and become members in a community ... is a necessary step upon which to enact citizenship." ${ }^{\prime 7}$ Ironically, the very act of exclusion, the forced displacement, is what creates the condition for inclusion in political life. The movement from the "tropics" to the city brings these populations into the realm of politics, where they are claiming a right to mobility and a right to the city, "citizenship created in motion-that is, by people on the move, who demand rights as political subjects, through acts of movement." 88 In spite of the discourse of tropicality, which has created a geographical divide and attached racist stereotypes to Indigenous peoples, Afro-Colombians, and Mestiza campesinas, the members of these communities are challenging these ideas with their practices. Race is difficult to contain within urban/rural borders, and race as a social construct that is in the making permanently, presents changes in space and time, challenging any static ideas of race in intersection with geography. I would like to conclude by sharing the words of Fernando, who speaks of the borders that Indigenous peoples, Afro-Colombians, and Mestiza campesinas are disrupting by practising their right to mobility, as well as the transformations that they are producing in the micro-geographies of daily life by acting out their right to the city.

In the neighbourhoods where we live, when we arrived for the first time, we were provoked a lot because we arrived at a very difficult neighbourhood to live in. But we have been very intelligent to gain their trust, because we didn't lose it when we were provoked. We went to the park to play, and they came in and said, "You're not from here, you're just a bunch of newcomers." But we didn't react. Now, as a result, they don't say anything. They respect us. They say, "We see that you're a community, we see that you're organized, we see how you are."

\section{Notes}

1 I would like to thank the guest editors, editors, and anonymous reviewers for their insightful comments and suggestions.

2 Translation by the author. All translations by the author are marked with an asterisk. Ana Cecilia Fajardo Rojas, "Paz, Justicia, Convivencia y Desarrollo: Palabras Constructoras de Humanidad en Ríoviejo y Arenal," in Relatos desde la memoria: Sistematización de experiencias del Programa de Desarrollo y Paz del Magdalena Medio, edited by Oscar Hernando Suárez Arévalo, Manuel Bayona Sarmiento, and Julián Gutiérrez Castaño (Barrancabermeja: PDPMM, 2005), 52.

3 Indigenous people and Afro-Colombians are recognized by the Colombian state as ethnic groups and as such are given special status in the National Constitution, but they are also subjected to racial discrimination. Mestiza campesinas are not recognized officially as an ethnic group or a racial category, but one of the points that I will make in this article is that this group is not part of the normative population in Colombia, which is composed of Whites and urban Mestizas. Additionally, in rural spaces, the way of life of Mestiza campesinas has many similarities with 
that of Indigenous and Afro-Colombians, and, similarly to these two groups, they are also subjected to racism in urban spaces. This article uses Mestiza campesina and other feminine nouns as the normative nouns for both genders, male and female. Traditionally, Spanish uses the termination $o$ to mark male gender, while it uses the termination $a$ to indicate female gender. Masculine words have the capacity to represent both genders, while feminine words contain only the female gender. I decided to use feminine words as normative to challenge the imposition of patriarchy in the language, briefly defined by Gregory et al. as "a system of social structures and practices through which men dominate, oppress and exploit women"; and to accept Anzaldúa's invitation to men to create new masculinities, for men to have "the courage to expose themselves to the woman inside them and to challenge the current masculinity." Derek Gregory, Ron Johnston, Geraldine Pratt, Michael Watts, and Sara Whatmore, The Dictionary of Human Geography, 5th ed. (Oxford: Wiley-Blackwell, 2009), 522; Gloria Anzaldúa, Borderlands/La Frontera: The New Mestiza (San Francisco: Aunt Lute Book, 1987), 106.

4 See Centro Nacional de Memoria Histórica, Una Nación Desplazada: Informe Nacional del Desplazamiento Forzado en Colombia (Bogotá: CNMH-UARIV, 2015).

5 For further information, see Peter Wade, Blackness and Race Mixture: The Dynamics of Racial Identity in Colombia (Baltimore: Johns Hopkins University Press, 1993); Wade, "Mestizaje, Multiculturalism, Liberalism, and Violence," Latin American and Caribbean Ethnic Studies 11, no. 3 (2016): 323-43; Wade, "Estudios Afrodescendientes en Latinoamérica: Racismo y Mestizaje," Tabula Rasa 27 (2017): 23-44.

6 For further information, see Arturo Escobar, El Final del Salvaje: Naturaleza, Cultura y Política en la Antropología Contemporánea (Bogotá: CEREC e ICAN, 1999); Escobar, "Displacement and Development in the Colombian Pacific," International Social Science Journal 175 (2003): 157-67; Escobar, "Mundos y Conocimiento de Otro Modo," Tabula Rasa 1 (2003): 51-86.

7 See Ulrich Oslender, "Violence in Development: The Logic of Forced Displacement on Colombia's Pacific Coast," Development in Practice 17, no. 6 (2007): 752-64.

8 For further information, see Eduardo Restrepo and Axel Rojas, Afrodescendientes en Colombia: Compilación Bibliográfica (Popayán: Universidad del Cauca, 2008); Restrepo, "Cuerpos Racializados," Revista Javeriana 146, no. 770 (2010): 16-23; Restrepo, Etnización de la Negridad: La Invención de las "Comunidades Negras" como Grupo Étnico en Colombia (Popayán: Universidad del Cauca, 2013).

9 See Santiago Castro-Gómez, La Hybris del Punto Cero: Ciencia, Raza e Ilustración en la Nueva Granada (1750-1816) (Bogotá: Editorial Pontificia Universidad Javeriana, 2005).

10 Bare life is a life that is not worth living, one in which the biological dimension is more relevant than how life is lived. Moreover, if the lives of IDPs are reduced to bare life, they are disposable. For further information, see Giorgio Agamben, Homo Sacer: Sovereign Power and Bare Life (Stanford: Stanford University Press, 1998).

11 See Henry Lefebvre, Writing on Cities, ed. Eleonore Kofman and Elizabeth Lebas (Oxford: Blackwell, 1996); Kanishka Goonewardena, Stefan Kipfer, Richard Milgrom, and Christian Schmid, eds., Space, Difference, Everyday Life: Henri Lefebvre and Radical Politics (New York: Routledge, 2008).

12 See Daniel Clayton and Gavin Bowd, "Geography, Tropicality and Postcolonialism: Anglophone and Francophone Readings of the Work of Pierre Gourou," L'Espace Géographique 3, no. 35 (2006): 208-21. The concept of tropicality should not be confused with the concept of tropicalism, which Linke uses to explain Europe's fascination with mega-slums from the Global South, "represented as spaces of color, natural abundance, childlike creativity, and happy natives." Uli Linke, "Racializing Cities, Naturalizing Space: The Seductive Appeal of Iconicities of Dispossession," Antipode 46, no. 5 (2014): 1225.

13 See Edward Said, Orientalism (New York: Vintage Books, 1978).

14 Clayton and Bowd, "Geography, Tropicality and Postcolonialism," 206.

15 Sandro Mezzadra and Neilson Brett, Border as Method, or, the Multiplication of Labor (Durham, NC: Duke University Press, 2013), 34.

16 The Viceroyalty of Nueva Granada was the colonial administration that included the territory that today is known as Colombia.

17 See Castro-Gómez, La Hybris del Punto Cero.

18 Most cities in Colombia are located in the Andean mountains over 1,000 MASL. Bogotá and Popayán, where the most distinguished tropicalists were based, are both over 2,000 MASL. These high altitudes were used to justify tropicality's comparison between "temperate highlands" and "extreme and indolent tropical lowlands." For further information, see Clayton and Bowd, "Geography, Tropicality and Postcolonialism”; Castro-Gómez, La Hybris del Punto Cero.

19 Etienne Balibar, Politics and the Other Scene (London: Verso, 2002), 77. Brahinsly, Sasser, and Minkoff-Zern offer the example of Latin American rural immigrant workers in the United States as people forced to live invisible lives, to occupy impossible positions. Their work site is imagined as an idyllic space inhabited by White rural families, but they are also recognized as workers most suited for agricultural labour. Rachel Brahinsky, Jade Sasser, and LauraAnne Minkoff-Zern, "Space, and Nature: An Introduction and Critique," Antipode 46, no. 5 (2014): 1135-52.

20 See Lefebvre, Writing on Cities; Goonewardena et al., Space, Difference, Everyday Life.

21 James Parsons, Antioqueño Colonization in Western Antioquia (Berkeley: University of California Press, 1968), 4.

22 See Sarah Ahmed, Strange Encounters: Embodied Others in Post-Coloniality (New York: Routledge, 2000). 
23 See Departamento Administrativo Nacional de Estadística, La Visibilización Estadística de los Grupos Étnicos Colombianos (Bogotá, 2005).

24 For further information, see Jane Hill, "Language, Race and White Public Space," American Anthropologist 100, no. 3 (1999): 680-9; Rachel Slocum, "Whiteness, Space and Alternative Food Practice," Geoforum 38 (2007): 520-33; Sunera Thobani, Exalted Subjects: Studies in the Making of Race and Nation in Canada (Toronto: University of Toronto Press, 2007); Patricia Price, "At the Crossroads: Critical Race Theory and Critical Geographies of Race," Progress in Human Geography 34, no. 2 (2010): 147-74; Lynn Staeheli, Patricia Ehrkamp, Helga Leitner, and Caroline Nagel, "Dreaming the Ordinary: Daily Life and the Complex Geographies of Citizenship," Progress in Human Geography 36, no. 5 (2012): 628-44.

25 See Michael Omi and Howard Winant, Racial Formation in the United States: From the 1960s to 1990s (New York: Routledge, 1994).

26 See Carlos Vladimir Zambrano, ed., Etnopolíticas y Racismo: Conflictividad y Desafíos Interculturales en América Latina (Bogotá: Universidad Nacional de Colombia, 2003).

27 See Balibar, Politics and the Other Scene.

28 For further information, see Escobar, "Displacement and Development in the Colombian Pacific"; Escobar, El Final del Salvaje; Norberto Cortés Lombana, "Relación del conflicto armado en Colombia con el desplazamiento y la resistencia indígena," in Zambrano, Etnopolíticas y racismo, 221-52; Oslender, Violence in Development; Julián Gutiérrez Castaño, "La Autodeterminación: una Zancadilla al Desarrollo Empobrecedor," in Etnoeducación: una Propuesta Comunitaria para una Sociedad Diversa, edited by Maicol Ruíz Morales, Héctor Hernando Quintero Gómez, and Julián Gutiérrez Castaño, 37-57 (Pereira: Universidad Tecnológica de Pereira, 2009).

29 See Departamento Administrativo Nacional de Estadística, La Visibilización Estadística de los Grupos Étnicos Colombianos.

30 Raizal refers to a subcategory of Afro-descendants who inhabit the Colombian Islands in the Caribbean. Roma refers to Colombian descendants of Roma people.

31 Internalized racism refers to how people who are subjected to racism reproduce it against other people who are categorized in the same racial group or in other groups that are also subjected to racism. By doing this, people who are subjected to racism reinforce the racial hierarchy that puts whiteness on top and people of colour at the bottom. For further information, see Rita Kohli, Lindsay Pérez, and Robin Johnson, "Naming Racism: A Conceptual Look at Internalized Racism in us Schools," ChicanoLatino Law Review 26 (2006): 183-206; Richard Delgado and Jean Stefancic, Critical Race Theory: An Introduction (New York: New York University Press, 2012). Mestizas' aspiration to whiteness is a consequence of internalized racism and, more broadly, of the power of coloniality. In this case, Mestizas accept implicitly the racial "superiority" and try to "pass" as Whites. For further information, see Peter Wade, Blackness and Race Mixture: The Dynamics of Racial Identity in Colombia (Baltimore: Johns Hopkins University Press, 1993); Anibal Quijano, "Coloniality and Modernity/Rationality," in Globalizations and Modernities: Experiences and Perspectives of Europe and Latin America, edited by Göran Therborn and Lise-Lotte Wallenius, 41-51 (Stockholm: Forskningsradsnamnden, 1999); Marisol De la Cadena, Indigenous Mestizos: The Politics of Race and Culture in Cuzco Peru (Durham, NC: Duke University Press, 200o); Mónica Moreno Figueroa, "Distributed Intensities: Whiteness, Mestizaje and the Logics of Mexican Racism," Ethnicities 10, no. 3 (2010): 387-401.

32 For further information, see Frantz Fanon, Black Skin, White Mask (New York: Grove, 1967); Octavio Paz, El Laberinto de la Soledad (Mexico DF: Fondo de Cultura Económica, 1972); Anzaldúa, Borderlands/La Frontera.

33 For further information, see De la Cadena, Indigenous Mestizos; Sylvia Wynter, "Unsettling the Coloniality of Being/ Power/Truth/Freedom: Towards the Human, after Man, Its Overrepresentation-An Argument," CR: The New Centennial Review 3, no. 3 (2003): 257-337; Castro-Gómez, La Hybris del Punto Cero; Joanne Rappaport, The Disappearing Mestizo: Configuring Difference in the Colonial New Kingdom of Granada (Durham, NC: Duke University Press, 2014).

34 See Departamento, La Visibilización Estadística de los Grupos Étnicos Colombianos.

35 See United Nations High Commissioner for Refugees, State of the World's Refugees: In Search of Solidarity (Oxford: Oxford University Press for the Journal of Refugee Studies, 2012).

36 Erin Mooney, "The Concept of Internal Displacement and the Case for Internally Displaced Persons as a Category of Concern," Refugee Survey Quarterly 24, no. 3 (2005): 9.

37 Acción Social, "Desplazamiento Forzado en Colombia." 2010, 1.

38 See Acción Social, "Desplazamiento Forzado en Colombia." 39 See Consultoría para los Derechos Humanos y el Desplazamiento, "La Crisis Humanitaria en Colombia Persiste: El Pacífico en Disputa. Informe de Desplazamiento Forzado en 2012," Documentos CODHES 26.

40 See United Nations High Commissioner for Refugees, "UnHCR Country Operations Profile: Colombia," last modified July 1, 2014, http://www.unhcr.org/pages/49e492ad6 .html.

41 See Centro Nacional de Memoria Histórica, Una Nación Desplazada.

42 See United Nations High Commissioner for Refugees, "UnHCR Country Operations Profile: Colombia."

43 For further information, see Departamento Administrativo Nacional de Estadística, La Visibilización Estadística de los Grupos Étnicos Colombianos; Consultoría para los Derechos Humanos y el Desplazamiento, "La Crisis Humanitaria en Colombia Persiste." 
44 For further information, see Acción Social, "Desplazamiento Forzado en Colombia"; Defensoría del Pueblo, Persistencia del Desplazamiento Forzado Interno en Colombia: Dinámica del Desplazamiento Forzado en Colombia (Bogotá, 2011); United Nations High Commissioner for Refugees, "Situación Colombia Indígenas," last modified May 26, 2012, http://www.acnur.org/t3/fileadmin/Documentos/RefugiadosAmericas/Colombia/2012/Situacion_ Colombia_-_Pueblos_indigenas_2012.pdf?view=1; UNHCR, "Año Internacional de los y las Afrodescendientes: Colombia, Costa Rica, Ecuador y Venezuela," last modified May 26, 2011, http://www.acnur.org/t3/fileadmin/Documentos/ RefugiadosAmericas/Colombia/Situacion_Colombia_-Afrodescendientes_2011.pdf?view $=1$.

45 See Consultoría para los Derechos Humanos y el Desplazamiento, "La Crisis Humanitaria en Colombia Persiste."

46 Antioquia is the only non-racialized territory that is part of the five departments with the worst IDPs crises in Colombia. I cannot expand on the dynamics of this department here, but I note that its incidents of forced displacement are taking place near other racialized departments, which indicates that they could be affecting mainly racialized communities. For further information about the Pacific Coast, see Escobar, "Displacement and Development in the Colombian Pacific"; Departamento Administrativo Nacional de Estadística, La Visibilización Estadística de los Grupos Étnicos Colombianos; Oslender, "Violence in Development."

47 For further information, see Escobar, "Displacement and Development in the Colombian Pacific"; Escobar, El Final del Salvaje; David Harvey, "Neo-liberalism as Creative Destruction," Annals of the American Academy of Political and Social Science 610, no. 1 (2007): 21-44; Oslender, "Violence in Development"; Gutiérrez Castaño, "La Autodeterminación."

48 Drawing from Foucault's ideas, it can be argued that power is a field of interventions that seek to make populations more exploitative with the expansion of agricultural production and the general management of the economy for the benefit of the rational state. This process of modernization is supported by bio-power-power over population-and the power of discipline-power over the individual. Michel Foucault, "Society Must Be Defended," in Lectures at the Collège de France 1975-1976, 239-64 (New York: Picador, 1997); Foucault, "Governmentality," in Power: Essential Works of Foucault 1954-1984, 201-22 (New York: New Press, 2001).

49 For further information, see Escobar, "Displacement and Development in the Colombian Pacific"; Escobar, El Final del Salvaje.

50 For further information, see Gearóid Loningsigh, La Estrategia Integral del Paramilitarismo en el Magdalena Medio (Verlag Nicht Ermittelbar, 2002); Oslender, "Violence in Development"; Gutiérrez Castaño, "La Autodeterminación."

51 See Karl Marx, Capital 1 (Moscow: Foreign Languages Publishing House, 1959).
52 See Harvey, "Neo-liberalism as Creative Destruction."

53 Indigenous ancestral lands include legally recognized Indigenous resguardos and other territories that they inhabited continuously over many generations.

54 Many Mestiza campesinas communities are seeking to legalize these territories as zonas de reserva campesina, which are very similar to Indigenous resguardos. For further information, see Suárez Arévalo, Bayona Sarmiento, and Gutiérrez Castaño, Relatos desde la memoria.

55 See Escobar, El Final del Salvaje.

56 According to Marx, "The capitalist system pre-supposes the complete separation of the labourers from all property in the means by which they can realize their labour." Capital 1, 714 .

57 See Harvey, "Neo-liberalism as Creative Destruction."

58 Harvey, "Neo-liberalism as Creative Destruction," 34-5.

59 See Centro Nacional de Memoria Histórica, Una Nación Desplazada.

60 Harvey, "Neo-liberalism as Creative Destruction," 39.

61 For further information, see Escobar, "Displacement and Development in the Colombian Pacific"; Escobar, El Final del Salvaje; Harvey, "Neo-liberalism as Creative Destruction"; Oslender, "Violence in Development"; Gutiérrez Castaño, "La Autodeterminación."

62 See Wolfgang Sachs, "La Anatomía Política del Desarrollo Sostenible," in La Gallina de los Huevos de Oro: Debate Sobre el Desarrollo Sostenible, edited by Wolfgang Sachs, 9-53 (Bogotá: CEREC, 1996).

63 See James Sidaway, "Postcolonial Geographies: An Exploratory Essay," Progress in Human Geography 24 (2000): 591-612.

64 See Francisco Ramírez Cuellar, The Profits of Extermination: How U.S. Corporate Power Is Destroying Colombia (Toronto: Common Courage, 2005).

65 Escobar, "Displacement and Development in the Colombian Pacific"; Oslender, "Violence in Development."

66 Capital is continuously redrawing its territorial boundaries with "complex assemblages of power and law, which include but also transcend nation-states." In this case, the expansion is not just outwards from the nation-state; it is also inwards, covering territories within the nation that have not been completely subsumed by capitalism. Mezzadra and Neilson, Border as Method, 5-6; Sidaway, "Postcolonial Geographies."

67 Escobar, El Final del Salvaje.

68 Oslender, "Violence in Development," 762.

69 See Frantz Fanon, The Wretched of the Earth (New York: Grove, 2004), xiii.

70 For further information, see Wade, Blackness and Race Mixture; Castro-Gómez, La Hybris del Punto Cero; Rappaport, Disappearing Mestizo.

71 See Departamento Administrativo Nacional de Estadística, La Visibilización Estadística de los Grupos Étnicos Colombianos.

72 For further information, see Escobar, "Displacement and Development in the Colombian Pacific"; Oslender, "Violence in Development." 
73 Escobar, "Displacement and Development in the Colombian Pacific," 160.

74 For further information, see Escobar, El Final del Salvaje; Escobar, "Displacement and Development in the Colombian Pacific."

75 See Oslender, "Violence in Development," 761.

76 See Oslender, "Violence in Development," 755.

77 See Foucault, "Society Must be Defended," 255.

78 Escobar, "Displacement and Development in the Colombian Pacific," 157.

79 See Centro Nacional de Memoria Histórica, Una Nación Desplazada.

80 Agamben, Homo Sacer, 85.

81 Agamben, Homo Sacer, 83 .

82 For further information, see Lefebvre, Writing on Cities; Goonewardena et al., Space, Difference, Everyday Life.

83 For further information, see Transitory Article 55 of the Colombian National Constitution, and Law 70 of 1993.
84 See Tianna Paschel, "The Beautiful Faces of My Black People: Race, Ethnicity and the Politics of Colombia's 2005 Census," Ethnic and Racial Studies 36, no. 10 (2013): 1544-63.

85 For further information, see Juliet Hooker, "Indigenous Inclusion/Black Exclusion: Race, Ethnicity and Multicultural Citizenship in Latin America," Journal of Latin American Studies 37 (2005): 285-310; Restrepo, Etnización de la Negridad.

86 See Agamben, Homo Sacer.

87 Kim Rygiel, "Bordering Solidarities: Migrant Activism and the Politics of Movement and Camps at Calais," Citizenship Studies 15, no. 1 (2011): 2.

88 Rygiel, "Bordering Solidarities," 5.

Julián Gutiérrez Castaño is a PhD candidate in human geography and teaching assistant at York University. The author may be contacted at juliangc@yorku.ca 